\title{
The use of technological aids in the processing of bacterially infected sugar beet
}

\author{
Lyubov Belyaeva ${ }^{1, *}$, Mikhail Pruzhin ${ }^{1}$, Alla Ostapenko ${ }^{1}$, and Valentina Gurova ${ }^{1}$ \\ ${ }^{1}$ Federal Agricultural Kursk Research Center, 305021 Kursk Karl Marks str. 70b, Russian Federation
}

\begin{abstract}
In the technology of beet sugar, technological aids play a special role, but the effectiveness of their complex application in the processing of bacterially infected sugar beets requires study. A three-factor laboratory experiment was carried out on the basis of the D-optimal Box-Behnken plan of the second order for three levels of variation of the studied factors - the enzyme preparation Dextrasept 2, the antimicrobial agent Betacept and the defoamer Voltes FSS 93. The quality of 15 studied indicators of the state of intermediate products of the processes of obtaining and purification of diffusion juice, syrup was determined according to the generally accepted methods. The obtained regression equations adequately reflected the combined effect of these drugs on the state indicators. The highest variability (24.2-39.0\%) was observed for the turbidity of juices and syrup, and the deposition rate; the chromaticity, the content of high-molecular compounds, lactic acid, and the height of the foam column were characterized by an average variation $(12.7-17.8 \%)$. The sucrose content and the overall effect of purification of diffusion juice changed insignificantly $(0.4-3.0 \%)$. Contribution of the enzyme preparation to the variation of 6 indicators was more than $45 \%, 7-39$ $42 \%$ and $2-$ less than $10 \%$. Under the influence of the antimicrobial agent, 6 indicators changed by more than $45 \%, 5-33-43 \%$ and $4-$ less than $30 \%$.
\end{abstract}

\section{Introduction}

The beet sugar complex of the Russian Federation in recent years has been demonstrating positive development dynamics due to the application of innovations in the agrarian and food technology of white sugar from sugar beet. A certain share of the contribution to the efficiency of the functioning of the agricultural technology of sugar beet is made by chemical agents - fertilizers, foliar feeding, growth regulators, remedies, adjuvants, etc. [1$3]$. The food technology of sugar is also characterized by the use of various technological aids - antimicrobial, defoamers, enzyme preparations, antiscale, flocculants, etc. [4-6]. In fact, the created and applied means, solving many complex technological problems of the cultivation and processing of sugar beets, are innovative solutions. For rational use, it is relevant and in demand to consider the results of the complex application of various means in the agrarian-food system of sugar production.

Of particular interest is the study of the joint use of technological aids in the processing of bacterially infected root crops. The increase in the share of such root crops in the volume of processed beets is due to highly productive foreign breeding hybrids that are not adapted to diseases in the conditions of chernozem soil and do not have a sufficient level of storage capacity $[7,8]$. In recent years, an increase in the duration of production seasons has been noted, and with prolonged storage, root crops are more susceptible to wilting, freezing and thawing, and are susceptible to diseases.
In the bacterial microflora, mucus-forming bacteria are problematic, of which Leuconostoc mesenteroides bacteria dominate [9]. Their development and movement along the process flow leads to the accumulation in intermediate products of high-molecular compounds (HMC) of dextran and levan, organic acids, gases. These substances inhibit the flow of technological processes, reduce the quality of the resulting intermediate products. As a result, the consumer properties of the produced white sugar deteriorate, its yield decreases, and resource consumption increases $[10,11]$. The use of an enzyme preparation of the dextranase class, an antimicrobial agent and an antifoam agent at the stage of obtaining diffusion juice is aimed at eliminating negative processes (microbiological, foaming, formation of polysaccharides) [4-6]. However, the information provided does not contain full information about the complex effect of these funds on the quality state of the resulting intermediate products of the process in which they are used, and subsequent processes of the technological flow of sugar production.

In connection with the above, the aim of the research was to identify the patterns of the combined effect of an enzyme preparation, an antimicrobial agent and an antifoam agent on the behavior of indicators of the state of intermediate products of the processes of obtaining and purifying diffusion juice, obtaining syrup from sugar beet affected by mucous bacteriosis. 


\section{Materials and methods}

As technological aids, the enzyme-antiseptic preparation Dextrasept 2 according to Technical Conditions (TC) 20.14.64-001-09265941-2017 was used, containing dextranase and levanase, antimicrobial agent Betasept according to TC 2381-001-92287788-2014, antifoam Voltes FSS 93 according to TC 2226- 100-34686523-09.

Intermediate products were analyzed - diffusion and pre-defecated juices, juices of the first and second saturation, syrup obtained from mucous bacteriosis affected sugar beet roots, grown and intended for processing at the beet sugar factories of the Kursk region in the 2019-2020 production season.

Marker technological indicators are included in the composition of the observed indicators of the state of intermediate products. Purity was determined by polarimetric and refractometric methods on Saccharomat NIR W2 and DUR-SW; the content of HMC - by the method of alcohol precipitation; the height of the foam column - by the dispersion method; lactic acid content, chromaticity - by photometric method on Coloromat 100 with optical density measurement at wavelengths of 400 and $560 \mathrm{~nm} \mathrm{[12];} \mathrm{the} \mathrm{degree} \mathrm{of} \mathrm{infection} \mathrm{with} \mathrm{mucous}$ bacteriosis - by microscopic examination of a stained smear "crushed drop" on a Levenhuk D740T [4]; the sedimentation rate of the sediment was established by the change in the height of the sediment layer during the first 5 min, expressed in $\mathrm{cm} \mathrm{/} \mathrm{min;} \mathrm{turbidity} \mathrm{-} \mathrm{by} \mathrm{the}$ complexometric method according to the difference in the content of calcium salts - total and soluble [13].

The experimental part of the work was performed by modeling sequential technological processes: obtaining diffusion juice from beet shavings, its lime-carbon dioxide purification, obtaining syrup, observing the optimal existing technological regime and points of entry, doses of the drugs used in accordance with the technological documentation for their use.

The studies were carried out using a matrix of 13variant laboratory experiments based on the 2nd-order Doptimal Box-Behnken plan for three factors at three levels of their variation. The experimental scheme consisted of the combinations of factor A - the injected enzyme preparation in doses of 4,6 and $8 \mathrm{~kg} / 1000$ tons of beets, predetermined by the plan; factor B - an antimicrobial agent at doses of 1.0, 1.5 and $2.0 \mathrm{~kg} / 1000$ tons of beets and factor $C$ - antifoam at doses of 10,15 and $20 \mathrm{~kg} / 1000$ tons of beets. The obtained data were processed using the practical provisions of the theory of experiment planning based on regression analysis algorithms.

The statistical significance of the regression coefficients was determined by the Student's t-test by comparing their numerical values with a confidence interval at the level of $\alpha=0.05$. Fisher's test (F) with a level of $\alpha=0.05$ served as an indicator of the adequacy of the regression dependences. The coefficient of determination $\left(\mathrm{R}^{2}\right)$ was used to further characterize the adequacy of the regression equations.

The actual values of the state indicators for the variants of the experiment were presented in the form of a dimensionless scale of desirability based on regression dependencies [14]. In general, the generalized coefficient of desirability was obtained by the type of a multiplicative criterion by multiplying particular criteria that have the same weight in accordance with the geometric mean formula [15].

\section{Results and Discussions}

The results of assessing the variability of experimental data on the studied indicators of the state of intermediate products and their relationship with the maximum permissible values established for the processes of obtaining and purifying diffusion juice, obtaining syrup are shown in Table 1.

From the data in Table 1, it can be seen that the greatest variability (24.2-39.0\%) was possessed by such indicators of the state of intermediate products as the effect of purification of diffusion juice $\left(Y_{5}\right)$, deposition rate of pre-defecated juice $\left(Y_{6}\right)$ and juice of first saturation $\left(Y_{7}\right)$, turbidity of juice of first saturation $\left(Y_{8}\right)$ and syrup $\left(Y_{14}\right)$. For indicators, the content of HMC $\left(Y_{2}\right)$, the content of lactic acid $\left(Y_{3}\right)$, the height of the foam column $\left(Y_{4}\right)$, the chromaticity of the juice of the second saturation $\left(Y_{11}\right)$ and syrup $\left(Y_{15}\right)$ were characterized by an average variation $(12.7-17.8 \%)$. The purity of intermediate products and the overall effect of purification of diffusion juice varied insignificantly, within $0.4-3.0 \%$, which objectively reflected the behavior of these indicators in real production conditions.

Table 1. Influence of technological aids on the change in indicators of the state of intermediate products in relation to their maximum permissible values

\begin{tabular}{|c|c|c|c|c|c|}
\hline Stages & Indicators & $\begin{array}{c}\mathrm{Mi} \\
\mathrm{n}\end{array}$ & Max & $\begin{array}{c}\text { Coefficien } \\
\mathrm{t} \text { of } \\
\text { variation, } \\
\%\end{array}$ & $\begin{array}{c}\text { Maximum } \\
\text { permissibl } \\
\text { e values }\end{array}$ \\
\hline \multirow[t]{5}{*}{$\begin{array}{l}\text { Diffusio } \\
\mathrm{n} \text { juice }\end{array}$} & Purity, \% $\left(\mathrm{Y}_{1}\right)$ & $\begin{array}{c}89 . \\
9\end{array}$ & 91.1 & 0.4 & $>90$ \\
\hline & $\begin{array}{l}\text { HMC, \% to D.M. } \\
\text { weight }\left(\mathrm{Y}_{2}\right)\end{array}$ & $\begin{array}{c}1.6 \\
3\end{array}$ & 2.59 & 12.8 & $<2.1$ \\
\hline & $\begin{array}{l}\text { Lactic acid, } \mathrm{mg} / 100 \mathrm{~g} \\
\text { of juice }\left(\mathrm{Y}_{3}\right)\end{array}$ & 72 & 121 & 15.4 & $<100$ \\
\hline & $\begin{array}{l}\text { Height of the foam } \\
\text { column, } \mathrm{cm}\left(\mathrm{Y}_{4}\right)\end{array}$ & $\begin{array}{c}12 . \\
3\end{array}$ & 20.3 & 17.8 & $<15$ \\
\hline & $\begin{array}{l}\text { Purification effect, \% } \\
\left(\mathrm{Y}_{5}\right)\end{array}$ & 5.1 & 17.6 & 32.6 & $>10$ \\
\hline \multirow{3}{*}{$\begin{array}{l}\text { Pre- } \\
\text { package } \\
\mathrm{d} \text { juice } \\
\text { Juice of } \\
\text { the first } \\
\text { saturatio } \\
\mathrm{n}\end{array}$} & $\begin{array}{l}\text { Deposition rate, } \\
\mathrm{cm} / \min \left(\mathrm{Y}_{6}\right)\end{array}$ & $\begin{array}{c}0.4 \\
1\end{array}$ & 3.81 & 39.0 & $>1.5$ \\
\hline & $\begin{array}{l}\text { Deposition rate, } \\
\mathrm{cm} / \min \left(\mathrm{Y}_{7}\right)\end{array}$ & $\begin{array}{c}0.9 \\
5\end{array}$ & 4.65 & 33.5 & $>2.0$ \\
\hline & $\begin{array}{l}\text { Turbidity, } \mathrm{mg} / \mathrm{dm}^{3} \\
\left(\mathrm{Y}_{8}\right)\end{array}$ & 236 & 554 & 24.2 & $<500$ \\
\hline \multirow{3}{*}{$\begin{array}{l}\text { Second } \\
\text { saturatio } \\
\mathrm{n} \text { juice }\end{array}$} & Purity, $\%\left(\mathrm{Y}_{9}\right)$ & $\begin{array}{c}92 . \\
5\end{array}$ & 93.6 & 0.4 & $>93$ \\
\hline & $\begin{array}{l}\text { Turbidity, } \mathrm{mg} / \mathrm{dm}^{3} \\
\left(\mathrm{Y}_{10}\right)\end{array}$ & 78 & 129 & 13.7 & $<100$ \\
\hline & $\begin{array}{l}\text { Chromaticity, units of } \\
\text { opt. pl. } \\
\text { (ICUMSA unit) }\left(\mathrm{Y}_{11}\right)\end{array}$ & 115 & 186 & 12.7 & $<400$ \\
\hline \multicolumn{2}{|c|}{ Overall cleaning effect, $\%\left(\mathrm{Y}_{12}\right)$} & $\begin{array}{c}27 . \\
8\end{array}$ & 30.4 & 3.0 & $>30$ \\
\hline \multirow[t]{3}{*}{ Syrup } & Purity, \% ( $\left.\mathrm{Y}_{13}\right)$ & 93 & 94.1 & 0.4 & $<93.5$ \\
\hline & $\begin{array}{l}\text { Turbidity, } \mathrm{mg} / \mathrm{dm}^{3} \\
\left(\mathrm{Y}_{14}\right)\end{array}$ & 27 & 76 & 27.7 & $<30$ \\
\hline & $\begin{array}{l}\text { Chromaticity, units of } \\
\text { opt. pl. } \\
\text { (ICUMSA unit) }\left(\mathrm{Y}_{15}\right)\end{array}$ & 165 & 268 & 12.7 & $<600$ \\
\hline
\end{tabular}

At the same time, it was revealed that the maximum possible numerical values of many indicators were below the maximum permissible level established for them. 
These data indicated a sufficient degree of representativeness of the laboratory experiment results.

In determining the dependent manifestation of the influence of the studied factors, a special role belongs to the results of regression analysis. For this purpose, polynomial equations were obtained that quantitatively relate the effect of the enzyme preparation Dextrasept 2 (A), antimicrobial agent Betasept (B) and antifoam agent Voltes FSS 93 (C) on 15 output state indicators (responses $\mathrm{Y}_{1}-\mathrm{Y}_{15}$ ) of the studied intermediate products of technological processes of obtaining and purification of diffusion juice, obtaining syrup and predicted sugar yield (response $\mathrm{Y}_{16}$ ), taking into account only significant regression coefficients (Table 2 ).

The resulting equations (Table 2) had the Fisher criterion values that met the requirements of statistical adequacy $\mathrm{F}_{\text {fact. }}=0.30-1.85 ; \quad \mathrm{F}_{05}=2.80-2.92$ and coefficients of determination $\mathrm{R}^{2}=0.93-0.99$. The indicated dependences can find application in predictive calculations of indicators of the state of intermediate products of the processes of obtaining and purifying diffusion juice, obtaining syrup from bacterially infected sugar beets within the studied area of the factor space.

Table 2. Regression equations for natural values of factors, reflecting the patterns of change in indicators of the state of the investigated intermediate products by options of experience

\begin{tabular}{|c|c|c|c|c|}
\hline \multirow{2}{*}{ Status indicator } & \multirow{2}{*}{$\begin{array}{l}\text { Regression equations for natural values of } \\
\text { factors }\end{array}$} & \multicolumn{3}{|c|}{$\begin{array}{l}\text { Indicators of the adequacy } \\
\text { of the equation }\end{array}$} \\
\hline & & $\mathrm{F}_{\text {факт. }}$ & $\mathrm{F}_{05}$ & $\mathrm{R}^{2}$ \\
\hline$Y_{1}$ & $\begin{array}{l}Y_{1}=87.22+0.5850 \mathrm{~A}+0.625 \mathrm{~B}+0.0175 \mathrm{C}- \\
0.0363 \mathrm{AA}\end{array}$ & 0.30 & 2.85 & 0.98 \\
\hline$Y_{2}$ & $\begin{array}{l}Y_{2}=4.32-0.4100 \mathrm{~A}-0.445 \mathrm{~B}-0.0105 \mathrm{C}+ \\
0.0256 \mathrm{AA}\end{array}$ & 2.78 & 2.85 & 0.98 \\
\hline$Y_{3}$ & $\begin{array}{l}Y_{3}=217.35-7.0625 \mathrm{~A}-69.000 \mathrm{~B}-2.6750 \mathrm{C} \\
+3.000 \mathrm{AB}+1.400 \mathrm{BC}\end{array}$ & 0.88 & 2.92 & 0.94 \\
\hline$Y_{4}$ & $\begin{array}{l}Y_{4}=45.14-0.3938 \mathrm{~A}-0.700 \mathrm{~B}-3.2190 \mathrm{C}+ \\
0.089 \mathrm{CC}\end{array}$ & 1.04 & 2.85 & 0.99 \\
\hline$Y_{5}$ & $\begin{array}{l}Y_{5}=5.8462 \mathrm{~A}+6.525 \mathrm{~B}+0.1800 \mathrm{C}- \\
0.3610 \mathrm{AA}-21.90\end{array}$ & 1.75 & 2.85 & 0.97 \\
\hline$Y_{6}$ & $\begin{array}{l}Y_{6}=0.8875 \mathrm{~A}+2.650 \mathrm{~B}+0.4680 \mathrm{C}- \\
0.2750 \mathrm{AB}-0.0146 \mathrm{CC}-7.92\end{array}$ & 0.55 & 2.92 & 0.95 \\
\hline$Y_{7}$ & $\begin{array}{l}Y_{7}=0.8750 \mathrm{~A}+2.800 \mathrm{~B}+0.4720 \mathrm{C}- \\
0.2500 \mathrm{AB}-0.0144 \mathrm{CC}-7.68\end{array}$ & 1.85 & 2.92 & 0.95 \\
\hline$Y_{8}$ & $Y_{8}=909.67-48.000 \mathrm{~A}-107.75 \mathrm{~B}-5.075 \mathrm{C}$ & 1.67 & 2.80 & 0.98 \\
\hline$Y_{9}$ & $\begin{array}{l}Y_{9}=89.90+0.5876 \mathrm{~A}+0.600 \mathrm{~B}+0.0150 \mathrm{C}- \\
0.0375 \mathrm{AA}\end{array}$ & 0.52 & 2.85 & 0.97 \\
\hline$Y_{10}$ & $\begin{array}{l}Y_{10}=214.37-22.437 \mathrm{~A}-19.250 \mathrm{~B}-0.700 \mathrm{C} \\
+1.406 \mathrm{AA}\end{array}$ & 1.06 & 2.85 & 0.96 \\
\hline$Y_{11}$ & $\begin{array}{l}Y_{11}=293.05-23.550 \mathrm{~A}-26.250 \mathrm{~B}-1.125 \mathrm{C} \\
+1.275 \mathrm{AA}\end{array}$ & 1.93 & 2.85 & 0.97 \\
\hline$Y_{12}$ & $\begin{array}{l}Y_{12}=12.09+2.474 \mathrm{~A}+9.371 \mathrm{~B}+0.1825 \mathrm{C}- \\
0.179 \mathrm{AA}-2.157 \mathrm{BB}-0.11 \mathrm{BC}\end{array}$ & 1.31 & 3.00 & 0.93 \\
\hline$Y_{13}$ & $\begin{array}{l}Y_{13}=90.40+0.5876 \mathrm{~A}+0.600 \mathrm{~B}+0.0150 \mathrm{C}- \\
0.0375 \mathrm{AA}\end{array}$ & 0.43 & 2.85 & 0.97 \\
\hline$Y_{14}$ & $\begin{array}{l}Y_{14}=209.52-34.835 \mathrm{~A}-42.000 \mathrm{~B}-0.375 \mathrm{C} \\
+2.044 \mathrm{AA}+3.750 \mathrm{AB}\end{array}$ & 0.96 & 2.92 & 0.97 \\
\hline$Y_{15}$ & $\begin{array}{l}Y_{15}=421.00-34.225 \mathrm{~A}-37.750 \mathrm{~B}-1.625 \mathrm{C} \\
+1.863 \mathrm{AA}\end{array}$ & 0.45 & 2.85 & 0.97 \\
\hline $\begin{array}{c}\mathrm{Y}_{16} \\
\text { (Predicted } \\
\text { sugar yield, \%) }\end{array}$ & $\begin{array}{l}Y_{16}=16.83+0.1096 \mathrm{~A}+0.123 \mathrm{~B}+0.0035 \mathrm{C}- \\
0.0067 \mathrm{AA}\end{array}$ & 0.09 & 2.85 & 0.97 \\
\hline
\end{tabular}

Regression analysis also revealed the features of changes in the contribution of the studied factors and their interactions to the variation of indicators of the state of intermediate products based on the results of obtaining and purifying diffusion juice, obtaining syrup (Fig. 1).

According to Fig. 1, three levels of influence of factor A (enzyme preparation Dextrasept 2) on changes in indicators of the state of the technological process of obtaining diffusion juice are distinguished: strong - more than $45 \%\left(Y_{6}, Y_{7}, Y_{8}, Y_{10}, Y_{11}, Y_{15}\right)$, average - 39-42\% $\left(Y_{1}\right.$, $\left.\mathrm{Y}_{2}, \mathrm{Y}_{5}, \mathrm{Y}_{9}, \mathrm{Y}_{12}, \mathrm{Y}_{13}, \mathrm{Y}_{14}\right)$ and weak - less than $10 \%\left(\mathrm{Y}_{3}\right.$, $\mathrm{Y}_{4}$ ). Factor $\mathrm{B}$ (antimicrobial agent Betacept) had a strong effect (more than $45 \%$ ) on indicators $\left(Y_{1}, Y_{2}, Y_{3}, Y_{5}, Y_{9}\right.$, $\left.\mathrm{Y}_{13}\right)$, average - 33-43\% $\left(\mathrm{Y}_{10}, \mathrm{Y}_{11}, \mathrm{Y}_{12}, \mathrm{Y}_{14}, \mathrm{Y}_{15}\right)$ and weak - less than $30 \%\left(\mathrm{Y}_{4}, \mathrm{Y}_{6}, \mathrm{Y}_{7}, \mathrm{Y}_{8}\right)$. Under the influence of factor C (defoamer Voltes FSS 93), the state of the Y4 indicator (height of the foam column, $\mathrm{cm}$ ) changed by $93 \%$. The contribution of this factor to the variation of other indicators ranged from 0.6 to $6.5 \%$. A noticeable quadratic effect of factor $A$ was revealed only for $\mathrm{Y}_{5}, \mathrm{Y}_{6}$, $\mathrm{Y}_{7}, \mathrm{Y}_{9}$, and $\mathrm{Y}_{10}$, and factor $\mathrm{B}$ - only for $\mathrm{Y}_{7}$ (overall effect of purification of diffusion juice, $\%$ ).

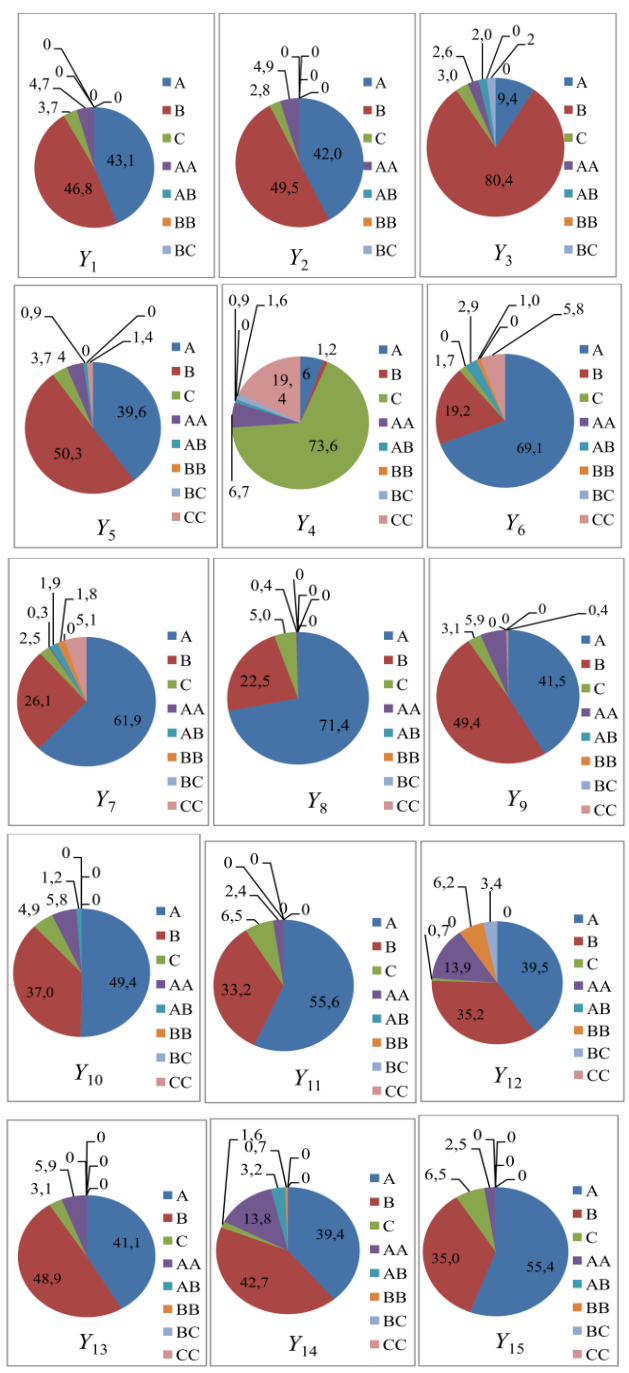

Fig. 1. The share of the contribution of the studied factors to the variation of indicators of the state of intermediate products based on the results of obtaining and purifying diffusion juice, obtaining syrup 
In general, the data in Fig. 1 illustrate the predominant influence of the main effects of the enzyme preparation and antimicrobial agent on the main indicators of the state of the studied intermediate products according to the variants of the experiment. The statistically significant role of the main effects of factors $\mathrm{A}, \mathrm{B}$ and $\mathrm{C}$ for those presented in Fig. 1 of the state indicators was due to the complex inhibitory effect of the triad of drugs on the bacterial infection of the diffusion juice in the process of its production due to the more efficient performance of its functional tasks. This afterwards had a positive effect on the course of subsequent processes of purification of diffusion juice and obtaining syrup.

The regression dependencies given in Table 2 for each individual state indicator $\left(\mathrm{Y}_{1}-\mathrm{Y}_{15}\right)$ do not allow obtaining a multi-criteria indicator of the influence of the studied factors on the response. To date, it has been established that a universal way to obtain such an estimate can be an optimization parameter, which is a multiplicative criterion for several particular parameters. One of such methods is Harrington's generalized desirability function (D), which is intended to be used as an optimization criterion $[14,15]$. For the numerical value of the specified criterion, the desirability scale is usually used: very good $1.00-0.80$; good $0.80-0.63$; satisfactorily $0.63-0.37$; bad $0.37-0.20$; very bad 0.20-0.00.

Based on the numerical values of 15 status indicators $\left(\mathrm{Y}_{1}-\mathrm{Y}_{15}\right)$, a comparative assessment of the generalized coefficient of desirability for all indicators (D) $\left(\mathrm{Y}_{1}-\mathrm{Y}_{15}\right)$ and the partial coefficient of desirability for the predicted sugar yield $\left(\mathrm{Y}_{16}\right)$ according to the laboratory experiment options is presented (Fig. 2).

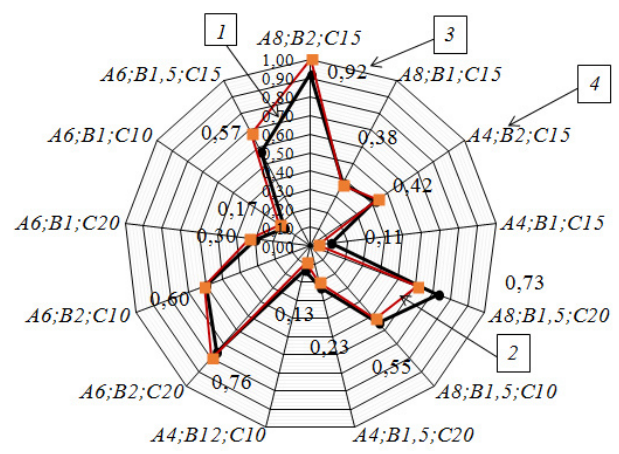

1 - generalized coefficient of desirability for all indicators (D); 2 - partial coefficient of desirability for the predicted sugar yield ( $\left.\mathrm{Y}_{16}\right) ; 3$ - values of the generalized coefficient of desirability (D); 4 - levels of variation of factors A, B and C.

Fig. 2. Dependence of the coefficients of desirability of state indicators on the dose of injection of an enzyme preparation, antimicrobial agent and antifoam

From the data in Fig. 2 it follows that with a combination of levels of variation of factors A8; B2; C15 and A6; B2; C20 generalized function of desirability (D) for all indicators $\left(\mathrm{Y}_{1}-\mathrm{Y}_{15}\right)$ for one-sided limitation corresponds to the level of optimal (maximum) values. This indicates the possibility of establishing doses of injected drugs based on generalized information about the behavior of indicators of the state of the processes of obtaining and purifying diffusion juice, syrup thickening.

\section{Conclusion}

The dependences of changes in 15 indicators of the state of intermediate products of the processes of obtaining and purifying diffusion juice, obtaining syrup from sugar beet affected by mucous bacteriosis with the combined injection of the enzyme preparation Dextrasept 2, antimicrobial agent Betasept and antifoam agent Voltes FSS 93 were revealed. It was found that the share of the contribution of the enzyme preparation to the variation of 6 state indicators took more than $45 \%, 7-39-42 \%$ and $2-$ less than $10 \%$. In turn, 6 indicators changed by more than $45 \%$ under the influence of the antimicrobial agent, 5 - by $33-43 \%$ and 4 - by less than $30 \%$. The change in only one indicator, the height of the foam column, by $93 \%$ was due to the influence of the defoamer, with its contribution to the change in the remaining indicators in the range of 0.6$6.5 \%$. The resulting equations had the Fisher criterion values that met the requirements of statistical adequacy $\mathrm{F}_{\text {fact. }}=0.30-1.85 ; \mathrm{F}_{05}=2.80-2.92$ and coefficients of determination $\mathrm{R}^{2}=0.93-0.99$. The above models, at a sufficient level of significance, are suitable for predictive calculations of the studied indicators of the state of intermediate products from bacterially infected sugar beet.

\section{References}

1. L.G. Campbell, K.K. Fugate. Sugar Beet Research, 53, 2 (2016)

2. S. Khodadadi, M.A. Chegini, A. Soltani, H.A. Norouzi, S.S. Hemayati. Sugar Tech, 22, 765 (2020)

3. V.V. Gamuev, O.V. Gamuev. Sugar beet, 8, 36 (2018)

4. V.A. Sotnikov, A.V. Sotnikov, V. Wilde, U. Moisch. Sugar, 4, 16 (2017)

5. T.I. Kostenko, M.V. Kuznetsova, V.N. Tarasov, V.S. Lebedev, N.P. Korotkova, T.V. Rudich. Sugar, 5, 39 (2014)

6. L.I. Belyaeva, M.K. Pruzhin, A.V. Ostapenko, V.N. Labuzova, T.I. Sysoeva. IOP Conf. Series: Earth and Environmental Science, 640, 052025 (2021)

7. Yu.S. Panicheva, M.V. Voronina, V.O. Gracis, A.N. Ignatov. Sugar, 11, 2 (2017)

8. L.N. Putilina, N.A. Lazutina, V.B. Chernogril. Storage and Processing of Farm Products, 2, 51 (2019)

9. S. Robles-Gancedo, T.M. Lopez-Diaz, A. Otero. International Sugar Journal, 116, 356 (2014)

10. K. Abraham, H. Brykczynski, E. S. J. RudolphFlöter, K. Schlumbach, A. Schäfer. Zuckerindustrie, 144 (10), 588 (2019)

11. L. Ying, L. Da-feng, L. Rong-Zhen, C. Guowei, M. $\mathrm{Bu}, \mathrm{L}$. Gui-Yun. International Sugar Journal, 120 (1432), 296 (2018)

12. L.I. Chernyavskaya, V.M. Milkevich, YU.A. Mokanyuk, V.P. Adamovich, P.M. Barabanov. Sugar, 10, 40 (2010) 
13. L.I. Chernyavskaya, YU.A. Mokanyuk, V.N.

Kukhar, A.P. Chernyavsky. Sugar, 11, 40 (2017)

14. N.P. Lyubushin, G.E. Brikach. Economic Analysis:

Theory and Practice, 13 (18), 2 (2014)

15. S. Pal, K. Gauri. International Journal of Engineering, Science and Technology, 10 (1), 76 (2018). 